\title{
THE NOMINAL PREDICATE \\ (ALBANIAN - ENGLISH)
}

\author{
Shkelqim Millaku \\ Prof. Assoc. Dr., Faculty of Philology \\ University of Prizren, Prizren, Kosovo
}

\begin{abstract}
:
The aim of this paper is to description the nominal of predicate between two languages (Albanian - English). The purpose of the following discussing is to show that some noun phrases, namely predicate nominal's, do not seem to exhibit. What is considering the typical behavior of noun phrase? First, they do not seem to be assigned case. Second, they may not assign are roles in normal sense so that they are probably as Theta-marker arguments, unlike referential Noun Phrases. ${ }^{\text {ii }}$ In Albanian language the nominal predicate can express with auxiliary verb (to be, have) and noun, too. "The predicate has the function of giving information about the subject..."
\end{abstract}

Keywords: predicate nominal, predicate, noun, verb, auxiliary verb, Albanian and English

\section{Introduction}

The purpose of the following discussing is to show that some noun phrases, namely predicate nominal's, do not seem to exhibit! What is considering the typical behavior of noun phrase? First, they do not seem to be assigned Case. Second, they may not assign are roles in normal sense so that they are probably as Theta-marker arguments, unlike referential Noun Phrases. ${ }^{\text {iii }}$

In Albanian language the predicate nominal can express with auxiliary verb (to be, have) and noun, too. "The predicate has the function of giving information about the subject... The case of the predicate noun requires further clarification, as its correct usage always presents the student with considerable difficulty. The following rule should be remembered: The predicate noun always adapted with the subject in case and number, too. If the predicate noun stands alone or is

\footnotetext{
${ }^{i}$ Correspondence: email shkelqim.millaku@uni-prizren.com

ii Elena Herburger. (1990). English noun phrase structure. Wien, p. 69.

iii Elena Herburger. (1990). English noun phrase structure. Wien, p. 69.
} 
augmented by an adjective, it stands in the indef. form as in the first sentence, regardless of the form of the subject." If, however, the predicate noun is augmented by a pronoun or noun in the definite form, it stands in the def. form (2).

1. Zogjtë dhe shtazët në përgjithësi janë frymorë.

The birds and the animals in general are living beings.

Macja dhe qeni quhen shtazë shtëpiake

The cat and the dog are called domestic animals

2. I tha gruaja atij. Ti je burri im. The woman said to him. You are my husband. ${ }^{\text {iv }}$

Both of languages the predicate noun following the verb e.g.:

Unë jam studenti dhe ju jeni mësuesi im. (NP)

I am student and you are my teacher. (NP)

Kjo ditë kishte për të qenë më e mira e menduar. (ADJ)

This day will be the best day of thinking. (NP)

John's mother does work at University. (NP)

Studentët janë ardhmeria e jetës. (NP)

Njeri që flet si dhelpër pak punë kryen. (NP)

Kush janë ata studentë atje. (NP)

Cila është Arta. (pronoun)

Ky libër mos është i atij. (pronoun)

The predicate is the same in Albanian and English. In English language the predicate can express with verb, noun, pronoun, it is same and in Albanian e.g.

John's mother does work at University. The man gave me a bookv .

"Arbeni reads a newspaper. Arbeni lexon gazeten. Arbeni and Teuta read books. (Compoundix subject) Tome and Arta read and enjoys books. (Compound verb) Tome reads books and newspapers. (Compound direct object) Those are the sentences that consist of only one main clause and no subclasses. The noun Anna, (Teuta, John, Arbeni) is the subject, where the sang (works, speaks, read) is the predicate" vi.

In this example, John's mother is the subject of the original statement; works at University is the predicate.

\footnotetext{
iv Martin Camaj. 1984. Albanian Grammar. Wiesbaden, p. 236

v Shkelqim Millaku, The Function of Albanian and English Sentence, European Journal of English Language Teaching ISSN: 2501-7136 ISSN-L: 2501-7136, Volume 2 | Issue 3 | 2017, https://www.oapub.org/edu/index.php/ejel/article/view/830

vi Shkelqim Millaku, The Function of Albanian and English Sentence, European Journal of English Language Teaching ISSN: 2501-7136 ISSN-L: 2501-7136, Volume 2 | Issue 3 | 2017, https://www.oapub.org/edu/index.php/ejel/article/view/830
} 
The predicate nominative is the noun following a linking verb that restates or stands for the subject. Typically, a predicate nominative has the same value or grammatical weight as the subject.

"Further, bare singular predicate nominal's are found in Dutch, Portuguese, as well as in all Balkan and MS languages. Some examples of bare singulars as predicate nominal's in several languages are given (...). Alb:

a. Nëna ime është mësuese.

mother my is teacher

My mother is a teacher." vii

The predicate noun follows a form of the verb "to be" it is not usually same in Albanian and English e.g.

He is an engineer. (Here engineer is a predicate noun because it follows is)

One fore is where the predicate noun renames the subject of the sentence.

Artani was the actor. (Artani is the subject and actor is the predicate of noun and it follows the verb "was" the past tens of "to be").

Arta's father remains the leader in sales for our country.

The predicate noun phrase follows a form of the verb for example in Albanian language:

Atdhetaria është punë e parë për çdo intelektual. Naimi është poeti ynë kombëtare. Fëmijët janë lulet e jetës. Kjo s'është punë e juaj. Agimi është djali yt? “It can be an NP or any other structure in nominal function" viii.

The structure of the sentence between Albanian and English is different and it has the contrast in these phenomena of grammar e.g.

The simple sentence:

\section{Kjo është punaje juaj.}

This is youf job.

The predicate of noun phrase (in simple or compound sentence) is the same with the function but different with structure.

When the subject complement is NP, it is the predicate nominative. Since predicate nominatives are NPs that follow verbs in the predicate, they look at great deal like direct objects.

I am a student.

S $\quad \underline{P} \quad$ DO

\section{Predicate nominal}

vii Dalina Kallulli. (1999). The Comparative Syntax of Albanian. Durham, p. 85.

viii Shkelqim Millaku, The contrast of Direct Object..., Imperial Journal of Interdisciplinary Research (IJIR) Vol-

2, Issue-7, 2016 ISSN: 2454-1362, http://www.onlinejournal.in,

http://imperialjournals.com/index.php/IJIR/article/view/1320/1270 
I love a teacher.

S $\quad \underline{\mathbf{P}} \quad$ DO

\section{Predicate nominal}

I like a book.

S $\quad \underline{\mathbf{P}}$ DO

\section{Predicate nominal}

In the sentence I am a student, I and a student are noun phrase that refer to the same individual. If the speaker in the second sentence /I love a teacher/ uses a transitive verb, I and a teacher refer to different people.

The direct object and indirect object are both structures within the predicate e.g.

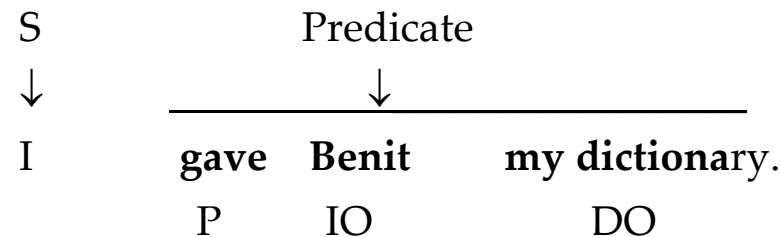

S Predicate $\downarrow$

Beni handed Artas the gift

IO DO

She always reads the book before breakfast.

$S \quad A \quad P \quad$ DO A (adjuncts-rrethanor)

I read the kids of story.

The function of the indirect object is normally realized by a noun phrase and only very rarely by a finite /kë, çka, çfarë, ku --- what, where, why, when/-clause etc. The direct object and indirect object are (can be) both structures within the predicate e.g.

$S \quad$ Predicate

I gave Benit my dictionary.

$\mathrm{P} \quad \mathrm{IO} \quad \mathrm{DO}{ }^{\mathrm{ix}}$

"Shkolla ka dhjetë studentë. In Albanian language the direct object can be the number that has the function of noun. When the subject complement is NP, it is the predicate nominative. Since predicate nominatives are NP-s that follows verb in the predicate, they look at great deal like direct objects.

I am a student.

S P DO

\footnotetext{
ix Shkelqim Millaku, The Indirect Object (Io) - Albanian and English, European Journal of Foreign Language Teaching ISSN: 2537 - 1754 ISSN-L: 2537 - 1754, Volume 1 | Issue 1 | 2016,

https://www.oapub.org/edu/index.php/ejfl/article/view/294/739
} 
Predicate nominal

Mësuesi do të flas më dekanin sot ${ }^{x}$.

I love a teacher.

S P DO

Predicate nominal

I like a book.

S P DO"xi.

\section{Predicator ${ }^{x i i}$ Complement}

Strictly complement could be used with reference to all those constituents that obligatory complement the verb. "Both of languages with this contrast in syntactic structure can make with noun the subject, direct object, indirect object and predicate" xiii.

The predicator complement can realize by the noun phrase e.g.

The boy resembles his father.

After a few minutes it began to rain.

Father suggests Tomin to see a doctor.

Could you help me to find this book?

The weather became warmer.

\section{I saw her in the street.}

We call him Jo.

If the predicate complement is realized by a non-finite clause containing a toinfinitive, the infinitive may be preceded by a noun phrase functioning as direct object of the finite verb, as in: ${ }^{\text {iiv }}$ Mother persuaded Mary to see a doctor.

Could you help me to move this cupboard?

In English language it is obligation to repeat the predicate and subject too, but in Albanian is not necessary to repeat the subject, because by the predicate we understand for what does the sentence has meaning. The sentence "The cat killed the mouse" we have the definite

\footnotetext{
× Shkelqim Millaku, Raporti i fjalive të thjeshta dhe kryefjalës ndërmjet shqipes dhe anglishtes, https://www.academia.edu/29764804/Raporti i fjalive te thjeshta dhe kryefjales ndermjet shqipes dhe angl ishtes

xi Shkelqim Millaku, The Direct Object, Anglisticum... Volume 4, issue 1, 2015, e-ISSN: 1857-8187, p-ISSN: 1857-8179,

xii Shkelqim Millaku, The Subject between Albanian and English Language, Anglisticum, April $2014 \square$ e-ISSN: 1857-8187 $\square$ p-ISSN: 1857-8179, http://www.anglisticum.org.mk/index.php/Anglisticum/article/view/621/1450 xiii Shkelqim Millaku, The Nominal Clauses of English and Albanian Language, Imperial Journal of Interdisciplinary Research (IJIR) Vol-3, Issue-8, 2017 ISSN: 2454-1362, http://www.onlinejournal.in http://www.imperialjournals.com/index.php/IJIR/article/viewFile/5472/5264

xiv Flor Aarts. (1988). English syntactic structure. Cambridge, p. 143
} 
article "the" that use before the noun, and in Albanian it is contrast, it can use how suffix (Alb.) for example "the cat -- maca"xv.

The noun in the sentence can be direct and indirect object. It is same for both of languages. The direct object and indirect can make with noun, noun phrase, noun with preposition etc. The direct or indirect object is the second object in the sentence. "In both of languages the object normally follows the subject and the predicate"xvi.

\section{Conclusion}

In Albanian and English language the predicate nominal ${ }^{x v i i}$ can express with auxiliary verb (to be, have) and noun, too. The predicate has the function of giving the information for the subject (...). The case of the predicate noun requires further clarification, as its correct usage always presents the student with considerable difficulty. The predicator is also one of the main functional elements of a sentence. It can be identified by the following main principles.

\section{References}

1. Abney, S.P. (1987). The English noun phrase in its sentential aspect. Cambridge.

2. Aboh, E. O. (2004). The morphosyntax of complement-head sequences. New York.

3. Wojcicki, A. (1995). Constraints on suffixation, Tubingen. Germany.

4. Adams, V. (1973). An introduction to modern English word-formation. London.

5. Carnie, A. (2002). Syntax. Oxford.

6. Radford, A. (2004). English Syntax. Cambridge.

7. Radford, A. (1997). Syntactic theory and the structure of English. Cambridge.

8. Radford, A. (2004). English syntax. Cambridge.

9. Spencer, A \& Arnold Zwicky. (1998). The Handbook of Morphology, Malden (USA).

\footnotetext{
xv Shkelqim Millaku, The Function Of Albanian And English Sentence, European Journal of English Language Teaching ISSN: 2501-7136 ISSN-L: 2501-7136, Volume 2 | Issue 3 | 2017,

https://www.oapub.org/edu/index.php/ejel/article/view/830

xvi Shkelqim Millaku, THE INDIRECT OBJECT (IO) - ALBANIAN AND ENGLISH, European Journal of Foreign Language Teaching ISSN: 2537 - 1754 ISSN-L: 2537 - 1754, Available on-line at: www.oapub.org/edu, Volume 1 | Issue 1 | 2016, https://www.oapub.org/edu/index.php/ejfl/article/view/294/739 xvii Nominal clause as prepositional complement: This raises the question as to whether we should abandon the plan. Nominal clause with /that/ e.g. That she is still alive is a consolation. "The nominative absolute is almost a clause. It consists of a noun phrase with a partial predicate: He smoked briefly, his eyes following a pattern of concrete blocks in the school building: Shkelqim Millaku, The Function of Noun Phrases between Albanian And English, The 2016 WEI International Academic Conference Proceedings Vienna, Austria, http://www.westeastinstitute.com/wp-content/uploads/2016/05/Shkelqim-Millaku.pdf
} 
10. Downing, A \& Philip Locke. (2002). A university English grammar. London.

11. Becker, A \& Markus Bieswanger. (2006). Introduction to English linguistics. Germany.

12. Mark, A. (2005). What is Morphology. Malden.

13. Aronoff, M. (1992). Morphology now, State University of New York.

14. Aronoff, M. (1975). Word Formation in Generative Grammar. Cambridge.

15. Bas, A. (2008). English syntax and argumentation. Cambridge.

16. Baker, C.L. (1995). English Syntax. London.

17. Connor, F. (1993). The Meaning of Syntax. New York.

18. Kallulli, D. (19999). The Comparative Syntax of Albanian. Durham.

19. Adger, D. (2003). Core Syntax. Oxford.

20. Kruising, E. (1995). English Accidence and Syntax. Wien.

21. Herburger, E. (1990). English noun phrase structure. Wien.

22. Selkirk, E. (182). The syntax of Words. London.

23. Bach, E. (1966). An Introduction to Transformation grammar. New York.

24. Bach, E. (1968). Noun and Noun-Phrase. New York.

25. George, Y. (2006). The Study of language. New York.

26. Georgio, G. (2003). Sintaksa, struktura e ligjërimit, përkth. Blerta Topalli. Tiranë.

27. Gerhard, N. (1971). Papers in Contrastive Linguistics. Cambridge.

28. Gerrit, R. (1999). First Explorations in English Syntax. London.

29. Giordano, E. (1963). Fjalori i Arbëreshëve të Italisë. Bari.

30. Giorgio, G. (2003). Sintaksa (përkthyese Blerta Topalli). Tiranë.

31. Goçi, I. (1986). Antonimet e Gjuhës se sotme shqipe. Prishtinë.

32. Graeme, K. (2003). Structure and meaning in English. Great Britain.

33. Grup autoresh. (2002). Gramatika e Gjuhës shqipe I. Tiranë.

34. Grup autoresh. (2002).Gramatika e gjuhës shqipe II. Tiranë.

35. Ian, R. (1997). Comparative Syntax. London.

36. Ingo, P. (2003). Word-formation in English. Cambridge.

37. Jackenddoff, R. (1972). The structure of English noun. Cambridge.

38. Miller, J. (2002). An Introduction English syntax. Edimburg.

39. Bresnan, J. (1979). Theory of Complementation in English syntax. London.

40. Andeson, J. (1968). The grammar of case. London.

41. Andeson, J. (1975). Noun phrase as adjective. London.

42. Hewson, J. (1972). Article and noun in English. Paris.

43. Jensen, J. (1990). Morphology. Word Structure in Generative Grammar. Amsterdam.

44. Lyons, J. (1968). Introduction to theoretical linguistical. Cambridge.

45. Michael, L. J. (1973). Studies in English Generics. London.

46. Askedal, O, J. (2010). Noam Chomsky and language descriptions. Philadelphia. 
47. John, E. (1997). Oxford Practice Grammar. London

48. Jokl, N. (1972). "Naim be Frashëri e pasunimi i gjuhës shqipe”, Gjurmime albanologjike, Seria e shkencave filologjike II. Prishtinë.

49. Josif, M. (2005). Hyrje në sintaksën gjenerative. Prishtinë.

50. Josif, M. (2008). Rendi i fjalëve dhe struktura e fjalive kohore. Prishtinë.

51. Juhn, A. (1977). On case grammar, London.

52. Karl, R. (1982). Ctegorial grammar and word-formation, Tubingen. Germany.

53. Kayen, R. (1982). Nouns and Predicate, Glow. Newsletter.

54. Kazumi, M. (1979). Syntax and Style in Early English. Tokyo.

55. Langendoen, T. (1969). The study of syntax. New York.

56. Lasnik, H. (2002). The minimalit Program in Syntax. Cambridge.

57. Laurie, B. (1983). English word-formation. New York.

58. Laurie, B. (1983). English Word Formation. Cambridge.

59. Lawri, B. (1996). English Word-formation. Cambridge.

60. Lees, R. B. (1960). The Grammar of English Nominalization. The Hague. Mouton.

61. Leonard, B. (20099). The syntax of argument structure. Cambridge.

62. Newmark, L. (1982). Philip Hubbard, Peter Prifti. Standard Albanian, A reference grammar for students. Stanford, California. USA.

63. Leslie, D. Alan Riding. (2004). Essential Shakespeare handbook. London.

64. Lilane, H. (1997). The New Comparative syntax. London.

65. Lloshi, Xh. (1999). Stilistika dhe Pragmatika. Tiranë.

66. Loyd, G. (1974). Albanian phonology. Wiesbaden. Germany.

67. Lynn, B. (1999). English syntax. New York.

68. Lyons, J. (1970). Generative Syntax. Harmondsworth.

69. Lyons, J. (1984). Language Linguistics. Cambridge University Pres.

70. Camaj, M. (1984). Albanian grammar. Wiesbaden, Germany.

71. Matthews, P.H. (1984). Syntax, Cambridge.

72. Max M. (2002). Doing Grammar. New York.

73. Çeliku, M (...). (1996).Gramatika e gjuhës shqipe II. Tiranë.

74. Memushaj, R. (2008). Gjuhësi gjenerative. Tiranë.

75. Merxhani, B. (1998). Formula të Neoshqiptarismës. Prishtinë.

76. Michael, M. (2008). English and American literature. Stuttgart.

77. Michaela, M. (2005). English General Nouns. Liverpool.

78. Mita, J. (2005). Hyrje në sintaksën gjenerative. Prishtinë.

79. Nushi, M. (2003). Gjuha e sotme shqipe. Prishtinë.

80. Chomsky, N. (1972). Studies on semantics in generative grammar. Paris.

81. Chomsky, N. (1980). Rules and representation. Oxford, London. 
82. Chomsky, N. (1982). The generative enterprise. Dordrecht. Holland.

83. Chomsky, N. (1965). Aspects of the theory of syntax. Cambridge.

84. Chomsky, N. (1986). Knowledge of language. New York.

85. Chomsky, N. (2002). Syntactic Structures. New York.

86. Chomsky, N. (2007). Language and problems of knowledge, (përkth. në shqip Blerta Topalli). Tiranë.

87. Chomsky, N. 2010). Development of the Anglo-Saxon Language and Linguistic Universal. Philadelphia. Culicover, P. (1976). Syntax. New York.

88. Culicover, P. (1992). Syntax. London.

89. Culicover, P. (2005). Simple syntax. Oxford.

90. Culicover, P. (2007). Simpler syntax. Oxford.

91. Sgall, P (...). (1968). A functional approach to syntax, in generative description of language. New York.

92. Qesku, P. (2002). Fjalor Anglisht-Shqip, English-Albanian Dictionery. Tiranë.

93. Quirk R \& Sidney Greenbaum. (1985). A comprehensive grammar of the English language. New York.

94. Raymond, M. (1986). English Grammar In Use. Cambridge.

95. Van, R. (1997). Valinm Randy, LaPolla. Syntax. New York.

96. Huddleston, R. (1976). An Introduction to English transformation syntax. New York.

97. Huddleston, R., Geoffrey Pullum. (2002). The Cambridge grammar of the English language. Cambridge.

98. Millaku, Sh. (2009). Kontributi i Zellik Harris për gjuhësinë, IASH. Tetovë.

99. Millaku, Sh. (2015). Kërkime gjuhësore. Prizren.

100. Millaku, Sh. (2011). Studime gjuhësore I. Prishtinë.

101. Millaku, Sh. (2011). Strukturat sintaksore. Prishtinë.

102. Millaku, Sh. (2009). (Profesor Selman Riza dhe Albanologjia) Studimet e Selman Rizes në fushën e morfologjisë. Korçë, f. 143-150.

103. Millaku, Sh. (2011). Historiku i nyjës se prapme (kontrast me gjuhët ballkanike), Edukologjia, nr.2, f.81-96. Prishtinë.

104. Shkelqim Millaku, The Subject Between Albanian and English Language, Anglisticum, Vol.3, No.4, 2014, http://anglisticum.aassee.eu/index.php/Anglisticum/article/view/621/1450

105. Shkelqim Millaku, The Direct Object, Anglisticum, Vol.5, No.1, 2015, http://anglisticum.aassee.eu/index.php/Anglisticum/article/view/233/1721

106. Shkelqim Millaku, The 2016 WEI International Academic Conference Proceedings Vienna, Austria, http://www.westeastinstitute.com/wpcontent/uploads/2016/05/Shkelqim-Millaku.pdf 
107. Graeme Kennedy. (2003). Structure and Meaning in English a Guide for Teacher. Great Britain, p. 270.

108. Shkelqim Millaku, The Function Of Albanian And English Sentence, European Journal of English Language Teaching, Vol.2, Issue 3, 2017, https://www.oapub.org/edu/index.php/ejel/article/view/830

109. Noam Chomsky. (1972). Studies on semantics in generative grammar. Paris, p. 16.

110. Shkelqim Millaku, The Noun Phrase, Anglisticum, Vol.2, No.3, 2013, http://anglisticum.aassee.eu/index.php/Anglisticum/article/view/1254/1754

111. Shkelqim Millaku, Imperial Journal of Interdisciplinary Research (IJIR) Vol-2, Issue-7, $2016 \quad$ ISSN: 2454-1362, http://www.onlinejournal.in, http://imperialjournals.com/index.php/IJIR/article/view/1320/1270

112. Shkelqim Millaku, The 2016 WEI International Academic Conference Proceedings Vienna, Austria, http://www.westeastinstitute.com/wpcontent/uploads/2016/05/Shkelqim-Millaku.pdf

113. Shkelqim Millaku, The Direct Object, Anglisticum, Vol.5, No.1, 2015, http://anglisticum.aassee.eu/index.php/Anglisticum/article/view/233/1721

114. $\quad$ Virginia Tufte. (1971). Grammar as Style, London, p. 50.

115. Shkelqim Millaku, The Contrast And The Function Of The Gender Albanian To English Language, European Journal of English Language Teacher, Vol.2, Issus 4, 2017, http://www.oapub.org/edu/index.php/ejel/article/view/829/2366

116. Shkelqim Millaku, The Genetive, Anglisticum, Vol.4, No.4, 2015, http://anglisticum.aassee.eu/index.php/Anglisticum/article/view/1218/1692

117. Shkelqim Millaku, European Journal of English Language Teaching, Vol.1, Issue 1, 2016, http://www.oapub.org/edu/index.php/ejfl/article/view/294/739

118. Christa Jansohn. (2002). Companion to the new literatures in English. Berlin, p. 49.

119. Shkelqim Millaku, The Prefixes and Suffixes of Albanian and

120. English Language, Anglisticum, Vol.6, No.7, 2017, http://anglisticum.aassee.eu/index.php/Anglisticum/article/view/1483/1996

121. Shkelqim Millaku, The Genetive, Anglisticum, Vol.4, No.4, 2015, http://anglisticum.aassee.eu/index.php/Anglisticum/article/view/1218/1692

122. T. Givon. (1993). English grammar I. Philadelphia, p. 291.

123. Shkelqim Millaku, The Function Of Albanian And English Sentence, European Journal of English Language Teaching, Vol.2, Issue 3, 2017, file://C:/Users/Admin/Downloads/830-3223-1-PB.pdf

124. Shkelqim Millaku, The Function Of Simple Sentence Between 
Albanian And English, European Journal of English Language Teaching, Vol.2, Issue 1, 2017, http://oapub.org/edu/index.php/ejfl/article/view/828/2363

125. Shkelqim Millaku, The 2016 WEI International Academic Conference Proceedings Vienna, Austria, http://www.westeastinstitute.com/wpcontent/uploads/2016/05/Shkelqim-Millaku.pdf

126. Shkelqim Millaku, The Noun Phrase, Anglisticum, Vol.2, No.3, 2013, http://anglisticum.aassee.eu/index.php/Anglisticum/article/view/1254/1754

127. Pinker, S. (1984). Language Learnability of language development. London.

128. Mann, S. A. (1932). Short Albanian grammar. London.

129. Evertsen, L.S. (2004). Native American Literatures, New York.

130. Chalker, S, Edomnd Weiner. (1994). The Oxford dictionary of English grammar.

131. Givon, T. (1993). English grammar I. Philadelphia.

132. Givon, T. (1996). English grammar. Philadelphia.

133. Jupp, T.C \& John Milne. (1968). English sentence structure. London.

134. Kelmendi, T. (2006). Kështjella e sintaksës. Prishtinë.

135. Kelmendi, T. (2008). Studime sintaksore. Prishtinë.

136. Verlag, V. (1986). English Grammar. Berlin.

137. Harris, Z. (1951). Structural linguistic. London. 
Creative Commons licensing terms

Author(s) will retain the copyright of their published articles agreeing that a Creative Commons Attribution 4.0 International License (CC BY 4.0) terms will be applied to their work. Under the terms of this license, no permission is required from the author(s) or publisher for members of the community to copy, distribute, transmit or adapt the article content, providing a proper, prominent and unambiguous attribution to the authors in a manner that makes clear that the materials are being reused under permission of a Creative Commons License. Views, opinions and conclusions expressed in this research article are views, opinions and conclusions of the author(s). and European Journal of Literature, Language and Linguistics Studies shall not be responsible or answerable for any loss, damage or liability caused in relation to/arising out of conflicts of interest, copyright violations and inappropriate or inaccurate use of any kind content related or integrated into the research work. All the published works are meeting the Open Access Publishing requirements and can be freely accessed, shared, modified, distributed and used in educational, commercial and non-commercial purposes under a Creative Commons Attribution 4.0 International License (CC BY 4.0). 